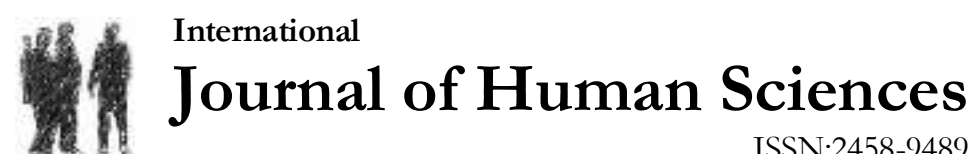

Volume 14 Issue 4 Year: 2017

\section{Old and new information in terms of text organization: Wilde's $A$ Woman of No Importance}

\author{
Ömer Şekerci ${ }^{1}$
}

\begin{abstract}
This study aims to analyse "given" (or old) versus "new" information and topicality in Oscar Wilde's $A$ Woman of No Importance (1893). It examines appropriate patterns from the mentioned functional styles in $A$ Woman of No Importance. It is a four-act- play. It is a society comedy. We have chosen the first act for analysis. The dialogues chosen from the first act are informal. Though numerous authors have written on the subject of "given" (or old) versus "new" information and topicality, it is hardly applied to drama texts. In order to analyse the deep structure of dramatic texts it is important to apply the principles of linguistics to drama. This study tends to analyse the selected play by Wilde from the perspective of "old" and "new" information and topicality. It deals with "givenness, predictability and relatedness". It covers how "old" and "new" information is defined by leading linguists and figures and its application to specified dialogues. The case with the interpretation of "givenness" is sought for in it.
\end{abstract}

Keywords: old and new information; text organisation; Wilde; givenness; drama.

\section{Introduction}

We contend that literary-based linguistic methodologies can foster and promote more effective drama analysis. Since a fuller integration of linguistics-based approaches to drama text study is regarded as a positive way of democratising access to drama texts. Understanding the connection between language and literature compel us recognize the ways which illuminate the textual character linguistically. Drama texts are the creative formations of spoken language, so they enable us to analyse such texts linguistically to delve into deep structure of them. As it is customary, drama texts are interpreted and analysed from textual analysis perspective. In this study, we try to interpret them from a linguistic point of view. The structure of dialogic genre does not only reflect the spoken language of social reality but also linguistic context.

Oscar Wilde was a protest poet, playwright and thinker against the ugliness, smugness, ideals and commonplace attitudes of his time. He had admirers and slanderers during his life time. He was a poet and playwright embodying feminine traits in the body of a man. His works embody the beauty of language, so they are rich sources for researchers to interpret and analyse his works from different perspectives.

It has been written much on the subject of "given" (or old) versus "new" information and topicality. Halliday 1976; Chafe 1974, 1976, 1978, 1994; Haviland and Clark 1974; Prince 1981, 1992; Ward 1990; Birner 1994, and Lambrecht 1994; to name a few. To Halliday, given information is that which is expected in a certain context, and new information is unexpected one in the

\footnotetext{
1 Assoc. Prof. Dr., Suleyman Demirel University, Faculty of Science and Letters, Department of English Language and Literature, omersekerci@,sdu.edu.tr
} 
discourse (1964: 201). Given or old information is what the sentence is about and the new information is always contrastive as opposed to predictability and alternative one. Halliday puts "given" vs "new" in terms of recoverability and predictability which is summarized by Prince as "the speaker assumes that the hearer can predict or could have predicted that a particular linguistic item will or would occur in a particular position within a sentence" (Prince 1981:226). We could infer that, to Halliday, a contrasted referent depicts new information, "not in the sense that it cannot have been, but in the sense that the speaker presents it as not being recoverable from the preceding discourse" (Halliday 1967: 204). He also furthers "new is always to be interpreted as "contrastive", as contrary to some predicted or stated alternative" (Ibid: 206). What these definitions tell us is that given information is anticipated in a definite context or environment and new information is not expected.

For Prince, "the general concept of given versus new information is prominently put under such names as "old-new", "known-new", "presupposition-focus" and so on, it has been invoked both in the explication of many sentence-level phenomena... and in the explication of how discourses are structured and understood" (1981: 325).

\subsection{Methodology}

The methodology is based on the following assumptions:

1) The chosen dialogic extracts from $A$ Woman of No Importance are investigated and interpreted as in line with "old" vs "new" information, "givennes", "predictability" and "topicality. The emphasis is on the way that how language is organized to enable conversation to implicate meanings which are explicitly or implicitly expressed by the characters. The reason why we have chosen Wilde's play for our analysis is that Wilde's aesthetic philosophy is given clearly in that work as it depicts art existing as an autonomous entity. It embodies beauties of language and art, so it provides us a plenty of material to interpret it from a linguistic perspective.

2) The qualitative research has been used in this study. It is based upon the drama text analysis. We place the socially interpretive methodology at the core of the study of the dialogic language in accordance with the mentioned linguistic units.

\subsection{Predictability / Givenness}

To Halliday and Hasan (1976), givenness or predictability is named as "given-new" information. On the other hand, Kuno names it as "old-new" information. Although the concepts are explained and defined quite differently by Halliday and Kuno, what is "old" for Kuno is not regarded as "given" by Halliday. According to Kuno, "old-new" information is defined in terms of predictability. It may be put as "an element in a sentence represents old, predictable information if it is recoverable from the preceding context; if it is not recoverable; it represents new, unpredictable information" (Kuno 1978: 282). It exhibits that recoverability and predictability are related with delectability. We cannot claim that it does not take into consideration other phenomena related to "given-new" information. As the following examples explain it well in the following. The antecedent is given as in (1):

(1) Joan paid Derek and he purchased himself a new hat.

If to compare (1) with (2):

(2) Derek paid Joan and he purchased himself a new hat.

It can be regarded that if the predictability was the sole criterion by which we assess the newness of an NP, "he" in (2) would be old whereas "he" in (1) would be new information. Halliday puts it as: "given-new" is defined in many ways in terms of intonation... thus labelled new is "information" that the speaker presents... as not being recoverable from the preceding discourse" (1967: 204). New expresses what the speaker presents as information which can be predicted and recovered from any source, environment and situation or the preceding text (Halliday 
and Hasan 1976: 326). But to Prince "it is still optional, since an information-unit may contain no given information" (1981: 226).

\subsection{Givenness}

Givenness as in the notion of saliency is defined by Prince as "givenness in the sense of 'saliency' as the speaker assumes that the hearer has or could appropriately have some particular thing/entirely/...in his/her consciousness at the time of hearing the utterance" (1981: 228). Moreover, Chafe defines it as "given information is about the knowledge that the speaker assumes to be in the consciousness of the addressee at the time of the utterance, and "new", "what the speaker assumes he is introducing into the addressee's consciousness by what he says" (1976: 30). What we could infer from the above statements and definitions is the known items which are given in the discourse for the first time are "new" or "unknown ones" (Ibid: 30). In order to qualify an NP we must explicitly introduce it in the discourse or provide the physical context as a referent. The following examples explicate it well. The beer "given" in (3a) and "new" in (3b):

(3) a. He got some beer out of the trunk. The beer was warm.

b. He got some picnic supplies out of the trunk. The beer was warm (Chafe 1976: 32).

According to Chafe, given items can be pronominalized as in the examples below.

Examples like (4a) and (4b) demonstrate that the inferred NPs in general. They can be shown as plausible given items:

(4) a. Pick two numbers, add six to the first number, and then multiply it by the second number.

b. In New York they drive very differently from the way they drive in Philadelphia. (Ibid: 31).

But the underlined NP in (5) is given "new".

(5). If I write loosely of a noun as being in the status given, what I really mean is that the idea which this noun expresses has this status (Ibid., 29).

For Prince, a difference between the givenness of "wh-clause" in (5) and the givenness of "he" in (6) can hardly be identified:

(6). [A to B as C passes by, in view and out of earshot]:

How old do you think he is? (Prince 1981: 230).

To Prince, the difference is that "some markers of givenness of pronouns correlate with a loss of explicit information such that understanding is greatly impeded if the item is not actually given, for the receiver, whereas other markers such as subject clauses with "wh-clefts do not correlate any loss of information and permit senders greater freedom in treating items as given" (Prince 1981: 233).

The interpretation of "givenness" in (6) cannot be restricted to only morphological and syntactic markers. We should take into consideration the pragmatic markers such as situation, communicants' knowing or not knowing the person cannot be ignored at all. The following example explicates it:

Case 1: The questioner knows the passer-by while the questionee does not know him.

The questioner knows the age of the passer-by, but it is clear that his moral and unacceptable clothing irritate him, so he wants to find out whether he is right or not in emphasizing the lack of harmony between the person's age and his moral and clothing. As this case shows it clearly, the givenness of the presupposed information will certainly be different for the two persons. And the reaction of the questionee could come down on with the opinion of his friend. The explications can differ as many times as the "givenness" grade changes. Therefore, language users should choose the appropriate linguistic forms for "given" and "new" items. 
To Chafe, "given-new" distinction and contrastive focus are independent of one another, and "a contrastive referent may be given, accessible, or new" (1994: 77). Furthermore, Chafe defines the term "given" as information that "the speaker assumes to be in the know of the hearer at the time it is spoken, whether or not it is predictable new information, on the other hand, is what the speaker assumes he is introducing into the addressee's consciousness by what he says" (Ibid., $30)$.

According to Prince, givennes is described as shared knowledge in speaker-hearer terms. He puts it as "the speaker assumes that the hearer knows, assumes, or can infer a particular thing" (1981: 230). But Clark and Haviland call it as "given-new information: given is information [the speaker] believes the listener already knows and accepts as true and new information [the speaker] believes the listener doesn't yet know" (Clark and Haviland 1977: 4). If the hearer knows the information directly or not being clearly informed about it, then, the indirect inference is insignificant. Thus "the beer" is given in both (3a) and (3b). Let' us see how it is given by Clark and Haviland in the following examples:

(7) a. Have you heard from Jane-Carol recently?

b. We got some beer out of the trunk and it was warm

c. Where were your grandparents born? (Ibid: 5).

It is a fact that " $(8 \mathrm{a})$ is much better than $(8 \mathrm{~b})$ is correlated with a tendency to put old information before new information, we are using old in the sense of shared knowledge (givenness) and not in the sense of predictability (givenness) or saliency (givennesss), as "John" and "a boy" are equally unpredictable and unsalient and differ only in that "John" is usually "given", whereas "a boy" is new" (Kuno 1972: 270).

(8) a. John hit a boy on the head.

b. a boy was hit on the head by John (Kuno cited. in Prince1981: 6).

The new information is described as the complement of old information. It is not in the immediate awareness of the hearer.

\subsection{Relatedness of the Three Types of Givenness}

We have tried to demonstrate it above; though in many cases the topics seem to represent old information. It is not necessary and sufficient for the topichood. They are different from one another. What we have observed is that the predictability and shared knowledge are not independent from each other. The case is put by Prince as:

If a speaker assumes that the hearer can predict some particular item or items will occur in some particular position within a sentence, then the speaker must assume that it is appropriate that the hearer has some particular thing in his/her consciousness. Then the speaker must assume that the hearer has some assumption or can draw some inference. Furthermore, all three levels sometimes involve cases where some item is "given" for extra linguistic reasons, showing that all levels must ultimately relate to extra linguistic phenomena, in particular to what the speaker thinks is or should be or could appropriately be in the hearer's mind (Prince 1981: 235).

Let us have a look at the following example:

“I graduated from high school as an average student. My initiative didn't carry me any further than average. History I found to be dry Math courses I was never good at. I enjoyed sciences... Football was my bag" (Haviland and Clark 1974: 516). 
The NPs above are not brought to mind and they are not in any element set relations to any discourse mentioned entity. But we can infer givennes from a set which is not mentioned. However we can infer it from the high school framework. If the hearer does not know its relation to high school which offers a set of modules, then, history and math modules actually represent the elements of the set. In other words, history and math modules can be inferred from high school teaching programme because the mentioned courses or modules are containing inferables. NP (high school) itself offers us a set-member as well as whole part, so the possible inferables are contained within the NP (Prince 1981: 236).

\subsection{A Woman of No Importance in Terms of Topichood and Functional Styles}

We can examine the appropriate patterns and the mentioned functional styles in A Woman of No Importance. It is a four-act- play. It is a society comedy. We have chosen the first act for analysis. The dialogues chosen from the first act are informal. The dialogues are interchanged by Lady Caroline, Hester and Sir John (Wilde 1997: 417-18). Wilde exposes a secret sin or indiscretion and disgrace in most of his works, so $A W$ oman of No Importance is a moralizing social comedy which combines teasing wit with sly observation of middle-class English manner and traditions. It was one of the most popular melodramas in the nineteenth century. It is about secrecy, decision, truth, and honour which were dear to everyone in the nineteenth century.

It deals with a single parent in Victorian era. During that period, a woman that became a single parent, given birth to an illegitimate child was not considered well in society. Though the play's language style is melodramatic pattern, the real issue is the attempt to pragmatize the theme of the individualist's situation in a conventional and hypocritical society. Wilde's society comedies are built upon the non-fulfilment of traditional and common theatrical plot devices such as a longlost orphan and a recognition or discovery scene (Pestka 1989: 175).

Thematic characterization in this comedy is grounded on a hierarchy of wit stemming from the Restoration pattern, according to which true wits are the sophisticated, mediating dandies who preserve their humane responses under the mask of triviality, like Lord Goring. Generally, Wilde's society comedy "a woman of no importance" is abundant in conversational gambits and the comic devices used in it are dandiacal paradoxes, witticisms or witty aphorisms that are grounded on different types of irony (Ibid: 176). The irony of reversal is the most frequent comic device of this comedy.

Contrary to the irony of the situation "it carries its context with itself" (Poague 1973: 251), and, like other types of irony, it constitutes witty remarks, retorts, and repartees. The comic device is exemplified by Lord Illingworth's epigram about marriage: "Men marry because they are tired; women because they are curious. Both are disappointed" (A Woman of No Importance: 436). The so-called "running joke" is a comic device often used in this society comedy. For instance, Lady Carolina continuously mispronounces Mr. Kelvil's name as "Ketle"; Lady Hunstanton suffers from bad memory and absent-mindedness; Lady Stuffield tends to use adverbs in pairs; and the archdeacon tells stories about his wife who is deaf and dumb, paralyzed, does not remember anything, but "has nothing to complain of" (A Woman of No Importance: 350).

We have purposely extracted the first Act in order to analyse it from the perspective of behaviour of the topichood. To realize this procedure, the first thing we should clarify is the different functional styles of language allowing the topics in accordance with their different types as well as their continuity. We are to check whether the claim that topics represent old vs new information which is empirically valid.

As the space does not let us analyse it in a detailed way, but it is worth mentioning a few critical points concerning the taxonomly hierarchy of different types of topics expressing "new" or "old or given" information. The topical subjects are raised, whereas half of the non-subject referents are not evoked. The great majority of non-subjects are new. The inferables give an account of almost one-fourth of the non-subjects. The inferables are mainly semantically 
Şekerci, Ö. (2017). Old and new information in terms of text organization: Wilde's A Woman of No Importance. Journal of Human Sciences, 14(4), 3230-3238. doi:10.14687/jhs.v14i4.4759

nominalization-based ones. They include the assumptions stemming from existential presuppositions.

\section{ACT ONE}

SCENE: Lawn in front of the terrace at Hunstanton Chase. The action of the play takes place within twenty-four hours.

TIME: The present.

SIR JOHN and LADY CAROLINE PONTEFRACT, MISS WORSLEY, on chairs under large yew tree.

LADY CAROLINE. I believe this is the first English country house you have stayed at, Miss Worsley?

HESTER. Yes, Lady Caroline.

LADY CAROLINE. You have no country houses, I am told, in America?

HESTER. We have not many.

LADY CAROLINE. Have you any country? What we should call country?

HESTER. [Smiling.] We have the largest country in the world, Lady Caroline. They used to tell us at school that some of our states are as big as France and England put together.

LADY CAROLINE. Ah! You must find it very draughty, I should fancy. [To SIR JOHN.] John, you should have your muffler. What is the use of my always knitting mufflers for you if you won't wear them?

SIR JOHN. I am quite warm, Caroline, I assure you.

LADY CAROLINE. I think not, John. Well, you couldn't come to a more charming place than this, Miss Worsley, though the house is excessively damp, quite unpardonably damp, and dear Lady Hunstanton is sometimes a little lax about the people she asks down here. [To SIR JOHN.] Jane mixes too much. Lord Illingworth, of course, is a man of high distinction. It is a privilege to meet him. And that Member of Parliament, Mr. Kettle

SIR JOHN. Kelvil, my love, Kelvil.

LADY CAROLINE. He must be quite respectable. One has never heard his name before in the whole course of one's life, which speaks volumes for a man, nowadays. But Mrs. Allonby is hardly a very suitable person.

HESTER. I dislike Mrs. Allonby. I dislike her more than I can say.

LADY CAROLINE. I am not sure, Miss Worsley, that foreigners like yourself should cultivate likes or dislikes about the people they are invited to meet. Mrs. Allonby is very well born. She is a niece of Lord Brancaster's. It is said, of course, that she ran away twice before she was married. But you know how unfair people often are. I myself don't believe she ran away more than once.

HESTER. Mr. Arbuthnot is very charming.

LADY CAROLINE. Ah, yes! The young man who has a post in a bank. Lady Hunstanton is most kind in asking him here, and Lord Illingworth seems to have taken quite a fancy to him. I am not sure, however, that Jane is right in taking him out of his position. In my young days, Miss Worsley, one never met anyone in society who worked for their living. It was not considered the thing.

HESTER. In America those are the people we respect most.

LADY CAROLINE. I have no doubt of it.

HESTER. Mr. Arbuthnot has a beautiful nature! He is so simple, so sincere. He has one of the most beautiful natures I have ever come across. It is a privilege to meet him.

LADY CAROLINE. It is not customary in England, Miss Worsley, for a young lady to speak with such enthusiasm of any person of the opposite sex. English women conceal their feelings till after they are married. They show them then.

HESTER. Do you, in England, allow no friendship to exist between a young man and a young girl?

[Enter LADY HUNSTANTON, followed by Footman with shawls and a cushion.]

LADY CAROLINE. We think it very inadvisable. Jane, I was just saying what a pleasant party you have asked us to meet. You have a wonderful power of selection. It is quite a gift.

LADY HUNSTANTON. Dear Caroline, how kind of you! I think we all do fit in very nicely together. And I hope our charming American visitor will carry back pleasant recollections of our English country life. [To Footman.] The cushion, there, Francis. And my shawl. The Shetland. Get the Shetland.

[Exit Footman for shawl.] [Enter GERALD ARBUTHNOT.]

GERALD. Lady Hunstanton, I have such good news to tell you. Lord Illingworth has just offered to make me his secretary. 

of Human Sciences, 14(4), 3230-3238. doi:10.14687/jhs.v14i4.4759

LADY HUNSTANTON. His secretary? That is good news indeed, Gerald. It means a very brilliant future in store for you. Your dear mother will be delighted. I really must try and induce her to come up here tonight. Do you think she would, Gerald? I know how difficult it is to get her to go anywhere.

GERALD. Oh! I am sure she would, Lady Hunstanton, if she knew Lord Illingworth had made me such an offer.

[Enter Footman with shawl.]

LADY HUNSTANTON. I will write and tell her about it, and ask her to come up and meet him. [To Footman.] Just wait, Francis. [Writes letter.]

LADY CAROLINE. That is a very wonderful opening for so young a man as you are, Mr. Arbuthnot.

GERALD. It is indeed, Lady Caroline. I trust I shall be able to show myself worthy of it.

LADY CAROLINE. I trust so.

GERALD. [To HESTER.] You have not congratulated me yet, Miss Worsley.

HESTER. Are you very pleased about it?

GERALD. Of course I am. It means everything to me things that were out of the reach of hope before may be within hope's reach now.

HESTER. Nothing should be out of the reach of hope. Life is a hope.

LADY HUNSTANTON. I fancy, Caroline, that Diplomacy is what Lord Illingworth is aiming at. I heard that he was offered Vienna. But that may not be true.

LADY CAROLINE. I don't think that England should be represented abroad by an unmarried man, Jane. It might lead to complications.

LADY HUNSTANTON. You are too nervous, Caroline. Believe me, you are too nervous. Besides, Lord Illingworth may marry any day. I was in hopes he would have married lady Kelso. But I believe he said her family was too large. Or was it her feet? I forget which. I regret it very much. She was made to be an ambassador's wife.

LADY CAROLINE. She certainly has a wonderful faculty of remembering people's names, and forgetting their faces.

LADY HUNSTANTON. Well, that is very natural, Caroline, is it not? [To Footman.] Tell Henry to wait for an answer. I have written a line to your dear mother, Gerald, to tell her your good news, and to say she really must come to dinner.

[Exit Footman.]

GERALD. That is awfully kind of you, Lady Hunstanton. [To HESTER.] Will you come for a stroll, Miss Worsley?

HESTER. With pleasure [Exit with GERALD.]

LADY HUNSTANTON. I am very much gratified at Gerald Arbuthnot's fortune... (Wilde 1997: 418419).

This- is evoked by situation, backward-looking crystalized by 'the first English country house' functioning as the 'new information' in relation to 'this' expressing 'old' information.

Country houses- equal to the existential presupposition. 'There are no country houses...' They are textually aroused and function as implied topic.

Country- is a conventional notion and it is cultural experience based upon 'known' information.

The largest country- is discourse participant's active knowledge; it is textually 'new' information.

They- is topicalized-subject, implied topic, 'knownness' coming from 'school', inferably-aroused knowledge, where 'they' is inferred from 'school'.

School- is a social institution, known from our social life and experience. It is 'given' (old) information. 
Some of our states- are inferably-aroused notion which is extracted from 'The USA' which is assumed knowledge of one's country. It functions as the 'new' information.

It- is an inferable entity as a result of nominalization of 'some of our states are as big as France and England together'. It is inferred from the knowledge given by school. It functions as 'known' information.

Muffler- is textually aroused 'knownness', so we can say that it is 'known' information.

Them- referring to 'muffles', it is textually aroused. Its referential referent is in the text; it is explicit 'knownness'.

(John) you- referring to explicit textual referent 'John', it is hearer-participant.

(the) house- textually evoked 'knownness', ironic use, containing inferable. It is 'Mrs. Hunstanton's house'. It is a referent of 'here'.

She- is aroused on textual grounds, it is 'knownness' topicality.

Him- is, from "Lord Illingworth", textually evoked, "known"; a man (of high distinction) inferable from "Lord Illingworth".

My love- the way Mr. Kelvil addresses his wife, evoked by situation, containing inferable, by a mutual relationship inference.

He- aroused inference, anaphoric, assumed 'knownness'.

His name- backward-looking refers to Lord Illingworth, assumed familiarity, aroused from the textual reference, giventity.

One- is evoked by situation. It is logically inferable from attitudinal meaning in the sense of 'nobody', topic-subject (Prince 1981).

\section{Conclusion}

All the other references found in the chosen part of act one resemble the functional as well as semantic features outlined for the elements of the examined part. Therefore, we necessarily pass to the behaviour of the so called referential topic-subjects in a narrative text, the findings of which will demonstrate the topic thematic continuity. Although "old" and "new" information is frequently applied to analyse literary texts, it is hardly applied to analyse drama texts. Applying the linguistic tenets and principles to drama text makes the analysis rich and effective to delve into the deep structure of the text. What we have done here is to approach a drama text from a linguistic perspective to open new windows for researchers and those interested in dealing with literary texts.

\section{Bibliography}

Chafe. W. (1976). "Givenness, Contrastiveness, Definiteness, Subjects, Topics and Point of View". In: Subject and Topic (Ed. C. Li). New York Academic Press. 25-55.

. (1987). "Cognitive Constraints on Information Flow". In: Russell Tomlin (ed.), Coherence and Grounding in Discourse, 21-51. Amsterdam: John Benjamin's.

Halliday, M. A. K. (1964). 'Descriptive linguistics in literary studies'. In: Alan. Duthie (ed.), Society, 201-16. 
. (1967). The Expression of Information Structure (Eds. Manfred Krifka \& Renate Musan). Berlin: De Gruyter Mouton.

Halliday, M.A.K, \& R. Hasan (1976). Cohesion in English. London: Longman.

Halliday, M.A.K. (1981). System and Function in Language. London: Batsford.

Haviland, Susan, E. \& H. Clark (1974). Psychological Processes as Linguistic Explanation. Washington D.C.: Hemisphere Publishing Corp.

Horn, L. R. (1978). "Some aspects of negation". In: J. Greenberg et al. (eds.), Universals of Human Language, vol. 4, 127-210. Stanford, CA: Stanford University Press.

Kuno, S. (1972). "Functional Sentence Perspective". Linguistic Inquiry, 3: 269-320.

. (1978). "Generative discourse analysis in America". In W. Dressler (ed.) Current trends in Textlinguistics. New York: Academic Press.

Pestka, D. (1989). “A Typology of Oscar Wilde’s Comic Devices.” Studia Anglica Posnaniensia 22: 175-93.

Poague, L. A. (1973). “The Importance of Being Earnest: The Texture of Wilde's. Irony”. Modern Drama, Volume 16, Number 3-4, Fall/Winter, 251-257.

Prince, A. (1981). "Toward a Taxonomy of Given-New Information". Radical Pragmatics, 223-255.

Reinhart, T. (1981). "Pragmatics and Linguistics: An Analysis of Sentence Topics". Philosophica, 27: 53-94.

Wilde, O. (1997). Collected Works of Oscar Wilde. Hertfordshire: Wordsworth Editions Ltd. 